Article

\title{
Increases in Household Food Waste in Canada as a Result of COVID-19: An Exploratory Study
}

\author{
Janet Music $^{1, *}$, Sylvain Charlebois ${ }^{2} \oplus$, Louise Spiteri ${ }^{2} \oplus$, Shannon Farrell ${ }^{2}$ and Alysha Griffin ${ }^{2}$ \\ 1 Faculty of Arts and Social Sciences, Dalhousie University, Halifax, NS B3H 4R2, Canada \\ 2 Faculty of Management, Dalhousie University, Halifax, NS B3H 4R2, Canada; sylvain.charlebois@dal.ca (S.C.); \\ louise.spiteri@dal.ca (L.S.); shannon.farrell@dal.ca (S.F.); Alysha.griffin@dal.ca (A.G.) \\ * Correspondence: jlmusic@dal.ca
}

check for updates

Citation: Music, J.; Charlebois, S.; Spiteri, L.; Farrell, S.; Griffin, A. Increases in Household Food Waste in Canada as a Result of COVID-19: An Exploratory Study. Sustainability 2021, 13, 13218. https://doi.org/ $10.3390 /$ su132313218

Academic Editor: Antonis A. Zorpas

Received: 7 November 2021

Accepted: 23 November 2021

Published: 29 November 2021

Publisher's Note: MDPI stays neutral with regard to jurisdictional claims in published maps and institutional affiliations.

Copyright: (C) 2021 by the authors Licensee MDPI, Basel, Switzerland. This article is an open access article distributed under the terms and conditions of the Creative Commons Attribution (CC BY) license (https:/ / creativecommons.org/licenses/by/ $4.0 /)$.

\begin{abstract}
The era of the COVID-19 pandemic has resulted in a variety of individual lifestyle and behavioural changes, and could, therefore, potentially involve a shift towards more sustainable food systems. This research was conducted through an online survey of cross-sectional design. We surveyed 8272 Canadians in August of 2020. Participants answered questions about sociodemographic food waste amounts in kilograms, and food-waste-management behaviours. In this exploratory study, we assessed the relationships between socio-demographic variables, and selfreported food-waste behaviours through two-tailed significance testing. Results indicated that Canadian households self-reported an insignificant decrease in food waste during the pandemic. Respondents reported allowing food to expire, not utilizing leftovers, and not finishing meals. Understanding food-waste behaviour changes is key to designing effective mitigation strategies to reduce household food waste and to minimize the environmental consequences with which food waste is associated.
\end{abstract}

Keywords: household food waste; COVID-19 pandemic; environmental impacts; Canadian households; sustainable food systems

\section{Introduction}

COVID-19, a respiratory illness caused by the SARS-CoV-2 virus, was identified in China in December 2019, and declared a pandemic by the World Health Organization (WHO) on 11 March 2020 [1,2]. As a result of the pandemic, lockdown measures have been enforced across the globe to slow the spread of the virus. There are no previous examples of global lockdowns on a scale similar to those evident during the onset of the COVID-19 pandemic [3]. The global lockdowns have resulted in major changes to daily lifestyles, forcing many of the world's populations to stay at home [4-8]. Some researchers believe that the experience of the COVID-19 pandemic will permanently change individuals' behaviours [9-11], including impacts on the individual, behavioural, and socioeconomic factors that influence food waste decisions [12-17]. These changes are not entirely understood yet within the context of COVID-19, and should be considered for further research because of the environmental implications of food waste.

The relationship between the COVID-19 pandemic and food waste is an important avenue of study for several reasons. The COVID-19 pandemic is a crisis that has raised unprecedented challenges for food waste in the global food supply system because of its disruption to food supply chains [18]. The issue of food waste is discussed because of its many environmental, social, and economic implications [15]. Food waste is also a critical factor in the development of food policy $[19,20]$. Thus, food waste is especially relevant within the context of the COVID-19 pandemic.

This study aims to address the growing environmental issue of food waste, by examining the impact of COVID-19 on household food waste, through a Canada-wide survey that was distributed in August 2020. The environmental implications of food waste are 
shown in the results of this survey, which highlight the need for urgent action to harness the COVID-19-induced changes in lifestyle and behaviour to reduce consumer food waste.

\section{Food Waste and COVID-19}

The COVID-19 pandemic has disrupted normal societal patterns in a variety of ways in a very short period of time. Consequently, household food consumption has been impacted by two overarching situations for most Canadians. A large number of service and retail employees have experienced the stress of income loss due to lockdowns [21,22], while a different, but equally large, group of generally 'white collar' employees were transitioned to telecommuting $[21,23,24]$. Many parents have been forced to supervise their children's online schooling, while working themselves [25-27]. These large-scale shifts in behavioural patterns have created new food consumption patterns. Early in the pandemic, when uncertainty about the robustness of food supply chains led to panic-buying, consumers began stockpiling non-perishable foods [28], indulging in calorie-dense snacks [29], and returning to the kitchen, as renewed interest in recipes and home-cooking dominated social media [30].

New habits surrounding food consumption have also led to new patterns of food waste during the pandemic. Food waste as a concept is difficult to define. Much of the focus has been on specific areas of production along the food supply chain over medium and long runs [31-35]. Yet, the very abrupt nature of change precipitated by the pandemic on food waste at the household level is not well understood. For the purposes of this study, the term 'food waste' is used to refer to household food waste that could have been avoided, if the food had been utilized in another way, instead of ending its lifecycle in a landfill.

The COVID-19 pandemic abruptly altered daily household food purchasing and consumption behaviours across the globe [12,36]. Many consumers built their food reserves to ensure regular levels of consumption [12,37]. There was an increase in the number of items that were purchased out of panic during this period $[28,37]$. These items exceeded standard levels of consumption in households, which could lead to increased food waste [37-39]. There are arguments, however, that these perceptions of scarcity may mean households could become more efficient in their use of food and planning of meals at home [40-42]. Despite uncertainties surrounding how these changes have impacted individuals, it is apparent that the pandemic has altered consciousness, concerns, and behaviours related to food waste [15,38].

Emergent research examined the impact of COVID-19 on changes in consumer behaviour in relation to food, including exploring food system sustainability [1,43], consumer food stockpiling behaviour [28,37], fruit and vegetable markets in North America [40], and over-ordering on online food apps [44]. Long-term changes in consumer food habits could include a potential growth in online grocery delivery services [44-47], a revived interest in local food supply chains [48-51], and persisting changes in people's economic and social lifestyles [2]. These lifestyle changes are seen as an increased or similar intake of meals (snacking or main meals), a similar or decreased intake of fast foods and junk foods, and a slight increase of eating out of boredom [52].

Yet, pandemic-driven food consumption patterns-stockpiling, cooking, and snacking-have impacted the volume of food waste in the short-term. There is evidence to suggest that consumers stopped prioritizing environmental impacts of waste during the pandemic, citing stress, and highlighting health outcomes as more important [53]. Yet, overall, consumers perceived that they wasted less food over the course of the pandemic, likely due to reports of over-eating [54], purchasing less fresh or perishable food [55], and potential scarcity of certain products [28].

The COVID-19 pandemic has illuminated weaknesses in the global food system by making global food waste visible and urgent. The impacts of the COVID-19 crisis are both a challenge and an opportunity to work towards solutions that could potentially serve people better, but to do so requires a commitment at local, regional, and global levels [43]. 
A food system transformation offers considerable potential benefits for both human and planetary health by slowing the destruction of habitats, decreasing the risk of supply and trade disruptions, and making fresh foods more accessible. The transition to a sustainable plant-based diet has been shown to have the largest environmental impact, due to the displacement of livestock as a primary protein source [56-58]. A food system transformation would build on the strategies that we saw during COVID-19 when communities came together to fill the gaps of food production, such as support for household and community gardening [48,49], calls for citizens to frequent local restaurants [59], renewed interest in cooking and sharing recipes [30], and supporting food charities [60]. A transformation of the food system could also help reduce health and dietary conditions that make people susceptible to disease, by providing access to more fresh produce.

Focusing on food waste prevention can yield cumulative impacts to mitigate climate change and to improve the environmental sustainability of food production $[18,61]$. The long-term resilience of the global food system is impacted by food waste, as food waste aggravates ecosystem damage [18], and food production is a major contributor to greenhouse gas emissions [62,63]. The environmental implications of household food waste are critical to consider. Food waste contributes to global environmental issues, such as extensive resource use and climate change, including the production of methane from landfilled food waste during decomposition [64-66]. The environmental impacts, together with increasing demand for food, high amounts of food wasted, and inefficient resource use, highlight the immense need for a more sustainable food system [20]. Transitioning to a more sustainable food system could serve to slow habitat destruction associated with food production [67]. The environmental impacts associated with the food system highlight the need to reduce the amount of food wasted. To do this, the various factors that impact household food waste must be examined.

This exploratory study sought to uncover the changes in volumes of household food waste and food management behaviour in Canadian households during the first half of the pandemic. Specifically, this research postulates that the change in Canadian consumers' behaviours influences their perceptions of the impact of COVID-19 on household food waste. This has significant ramifications for greenhouse-gas emissions [68], waste management policies [69], as well as both the physical and financial health and well-being of Canadian households. In addition to perceptions of household food-waste volume, this study seeks to understand the impact of COVID-19 on short- and medium-term food management behaviours, such as freezing, preserving, and cooking in Canadian households. Public health agencies took extraordinary measures over the spring of 2020 to reduce the spread of COVID-19 among the Canadian population by enforcing lockdowns and isolation measures. These actions had many consequences for consumers, including impacting their food preferences and behaviours. This resulted in negative outcomes for the health of individuals [70], but also for the overall health of the environment. The importance of understanding how Canadians perceive and mitigate waste behaviours during crises can influence the direction of many policy arenas in the future.

\section{Materials and Methods}

\subsection{Sample Management}

This exploratory study was designed as a cross-sectional, national survey. The population of interest included Canadians who had lived in Canada for 12 months and were over 18 years of age. Due to the exploratory nature of the study, the sample was not proportional. For this survey, a target of 10,000 respondents was sought. This number is not linked to the COVID-19 pandemic; rather, the large target responses provide more accurate data and eliminate any outliers that may be found in the data. The results consist of 8272 responses from participants in 10 provinces and one territory: Alberta $(n=769)$, British Columbia $(n=943)$, Manitoba $(n=339)$, New Brunswick $(n=240)$, Newfoundland and Labrador $(n=223)$, Northwest Territories $(n=8)$, Nova Scotia $(n=364)$, Ontario $(n=3846)$, Prince Edward Island $(n=41)$, Quebec $(n=1249)$, and Saskatchewan $(n=248)$. Of these, 
6534 respondents indicated that they were female, while 1738 were male. In terms of age categories, respondents were born between 1900-1946, Greatest Generation ( $n=50)$; 1947-1964, Baby Boomers $(n=1299)$; 1965-1980, Generation X $(n=2837)$; 1981-1996, Millennials ( $n=3664)$; and 1997-2005, Generation Z $(n=422)$.

\subsection{Data Collection}

Data were collected using an online survey during August 2020. The survey results carry a margin of error of $+/-3.1$ percentage points, 19 times out of 20. Any discrepancies in or between totals are due to rounding. Participants were invited to self-select for the survey from a proprietary panel owned by Caddle, a third-party marketing research firm. This panel consists of 100,000 Canadian volunteers who agreed to periodically answer surveys, for a chance to be selected for promotional offers with a monetary value of CAD $\$ 50$ or less. Ethics approval was granted by Dalhousie University's research ethics board, in accordance with the Tri-council Policy Statement: Ethical Conduct for Research Involving Humans. Participants granted consent before access to the survey instrument was made available. They could revoke consent by closing their browser, and no partial responses were recorded. Response times for the questionnaire were approximately 3-5 $\mathrm{min}$.

The study was conducted between the first and second waves of COVID-19 in Canada. At the time, it appeared that lockdowns and isolation measures had successfully reduced the prevalence of the virus to negligible levels in most Canadian regions. According to data from the Canadian federal government, across all regions, as of 21 August 2020, the end of the data collection period of this study, there were 128,948 confirmed cases of COVID-19 and 9126 deaths. At the time, it was not known whether the virus would make a resurgence, nor whether a vaccine would successfully protect the Canadian population from the serious effects of the disease.

\subsection{Survey Instrument}

The survey instrument consisted of five questions. First, respondents were asked to give a perceived measure in kilograms (Less than $2 \mathrm{~kg}, 2 \mathrm{~kg}$ to $4 \mathrm{~kg}, 4.01 \mathrm{~kg}$ to $6 \mathrm{~kg}$, $6.01 \mathrm{~kg}$ to $8 \mathrm{~kg}$, more than $8 \mathrm{~kg}$ ) of their weekly food waste before the COVID-19 pandemic, and during the pandemic. As this was an exploratory study designed to gauge whether respondents perceived a change in their food waste habits, efforts were taken to keep answers uniform and simple. Answer categories were chosen so that respondents from different socio-economic and regional backgrounds could be compared. In addition, it could have been the case that some respondents were not very knowledgeable about food waste; therefore, uniform answers would include them, despite their lack of knowledge about the topic. Next, they were asked whether they perceived that they were wasting more or less food, since the advent of the pandemic in March 2020 (We are wasting less food, in amount and overall percentage; We are wasting less food in amount, but not in overall percentage; We are wasting less food in percentage, but not overall amount; We are wasting more food, in amount and overall percentage). Respondents were then asked to list some of the reasons for their food waste (Some household members do not always finish their meals; We like to eat the freshest food possible; Family members change their plans (and they don't turn up for dinner); We're generally too busy to cook meals that we've planned; We aren't sure how to store food properly; We can't store food properly; Food is left too long in the fridge or freezer; We cook too much food; Food goes off before the 'use by' or 'best before' dates; We buy too much food; We don't check the fridge, freezer, or cupboards before going shopping; We tend not to plan meals in advance). Finally, respondents were asked about their food waste management techniques during this timeframe (I am eating leftovers more often; I am freezing, preserving, or canning surplus food more often; I am planning meals for the week more often before you go shopping, and buy only the things needed for those meals; I look in my refrigerator and cupboards first more often to avoid buying food you already have; Wait to wash some produce until you want to eat them to prevent mold; Prepare and cook perishable items more often, then freeze them for use 
throughout the month; You are using produce that is past its prime more often, and making soups, casseroles, stir fries, sauces, baked goods, or smoothies with them; I have not change anything since the start of the pandemic).

\subsection{Limitations}

There are several limitations with this study. First, the exploratory nature of the research allowed for a very short survey, categories for answers were given, and no open text was allowed. Second, the respondent demographics were not representative of the Canadian public. Therefore, results are presented as descriptive correlations and statistically using a two-tailed test of significance produced using Microsoft Excel. A twotailed test ( $p$ value) can only predict that there will be an effect, not the direction of the effect (increasing or decreasing), necessitating the need for further research. All reported $p$ values are statistically significant at the $95 \%$ confidence level $(\alpha=0.05)$. Finally, self-reported data are often inaccurate, since respondents tend to overreport or underreport behaviours in accordance with their aspirations. Regardless of limitations, the value of the research lies in the importance of the topic, and acts as a starting point for more in-depth analysis.

\section{Results}

\subsection{Canadians Report More Food Waste since Before the Start of the Pandemic}

The self-reported results of this survey suggest that Canadians may have been wasting less food since the start of the pandemic. According to the results represented in Figure 1a,b respondents reported a decrease in the amount of food they were wasting. Though more people were wasting less than $2 \mathrm{~kg}$ of food, this number does not represent a significant change $(p=0.573)$. Almost half $(46.9 \%)$ of the respondents believed that they were wasting less food, both in amount and overall percentage, since the beginning of the pandemic, with many reporting that they were wasting less food in amount, but not percentage $(29.0 \%)$, while others reported wasting more food in amount, but not percentage $(15.5 \%)$, and a few reported wasting more food in both amount and percentage (7.5\%). This indicates that some respondents believed that they were wasting less food overall, but may not actually have been doing so, compared to pre-pandemic amounts. There was a significant difference between those who felt that they were wasting less food (percentage and overall) than those who were wasting more (percentage and overall) $(p<0.00001)$.

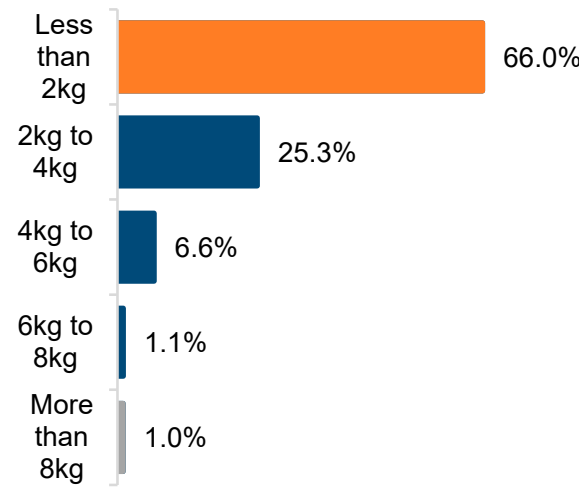

(a)

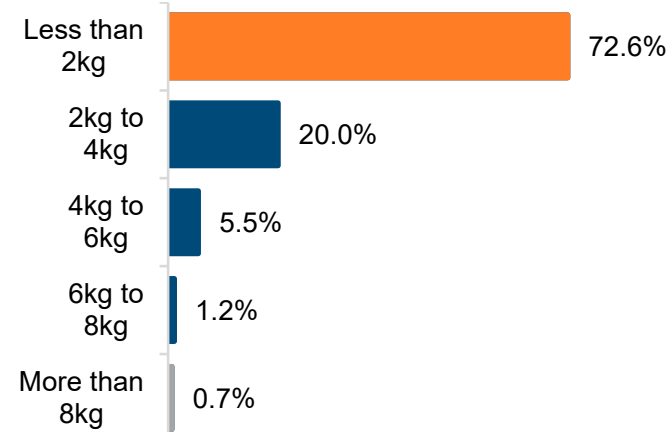

(b)

Figure 1. (a,b). Comparison of perceived weekly food waste, pre./post COVID-19 pandemic (in kg). (a): "Before the pandemic, how much food was your household wasting at home per week?"; (b): "Since the start of the pandemic, how much food is your household wasting at home per week?". 


\subsection{Food Waste Generating Behaviours}

Respondents reported various motivations for wasting food, but underlying each appears to be the issue of poor planning behaviours as shown in Figure 2. For example, poor planning was at the root of the most selected reason, "food is left in the fridge or freezer for too long" (31.3\%); that response was statistically higher $(p=0.016)$ than the next most popular options, "not consuming food before the best before or use by dates" $(15 \%)$ $(p=0.005)$, and, "preferring the freshest possible food" (12.8\%). Each of these could be addressed by improved planning behaviour, such as planning for shopping and cooking.

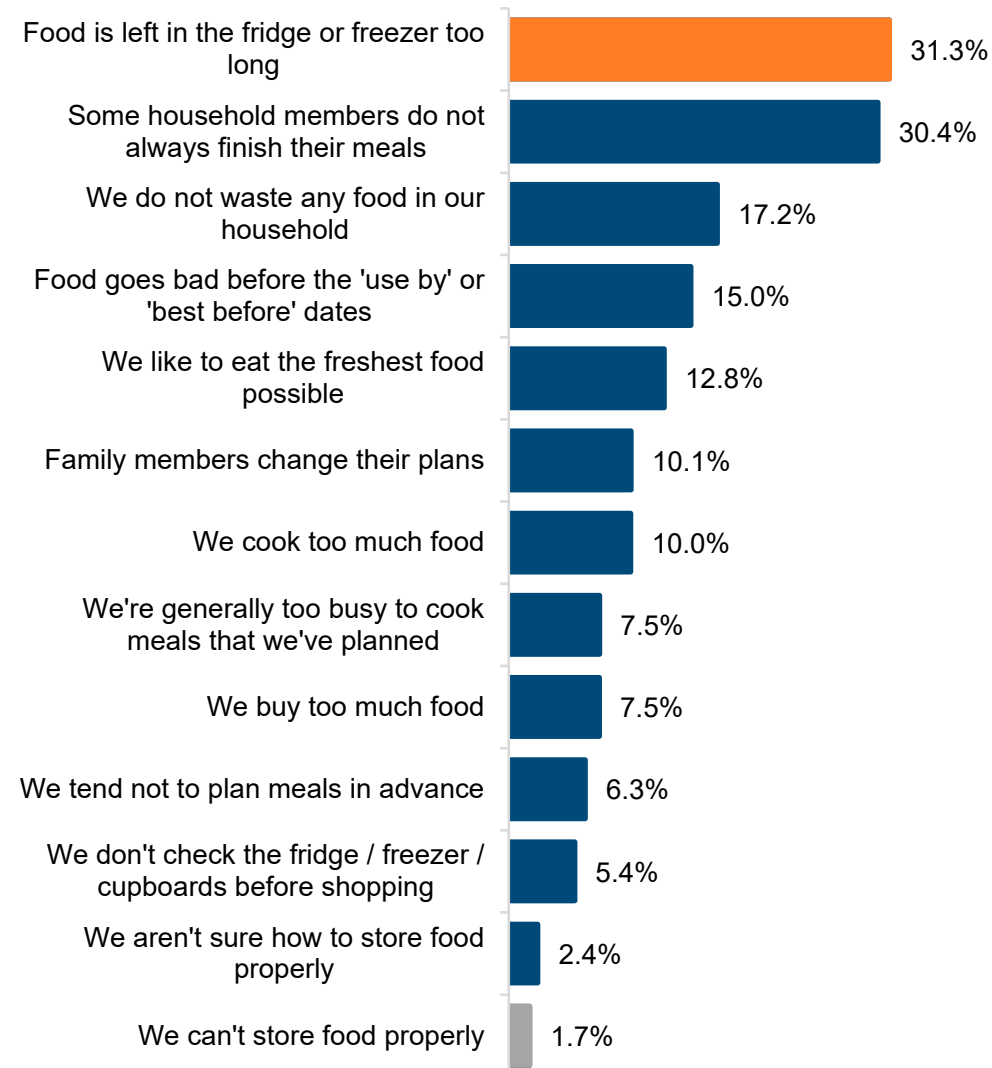

Figure 2. Food-waste-generating behaviours.

Interestingly, $17.2 \%$ of respondents reported not wasting any food at all. This is a statistically significant number of respondents $(p=00001)$. It could be that this group had always taken action to eliminate food waste and their behaviours had not been disrupted by the COVID-19 pandemic.

\subsection{Household Food Waste Management}

The survey asked about food-waste-managing behaviours. For example, one question asked respondents what they were doing differently now since the start of the pandemic (see Figure 3). The most frequent response was, "I am eating leftovers more often" (34.5\%), followed by other common responses, such as, "I look in my refrigerator and cupboards more often to avoid buying food I already have" (24.4\%); "I am freezing/preserving/canning surplus food more often" (22.5\%); and "I am planning meals for the week before shopping more often and only buying the required items" (21.1\%). This indicates that households have been making changes to try to reduce food waste since the start of the pandemic. Results suggest that the percentage of people who had implemented a change to mitigate food waste (34.5\%) over those that had not $(27.2 \%)$ is not statistically significant $(p=0.352)$. Yet, among those that had implemented new waste management techniques, none of these responses were statistically significant over the 
others, suggesting that no one food waste management technique has gained prominence during the pandemic.

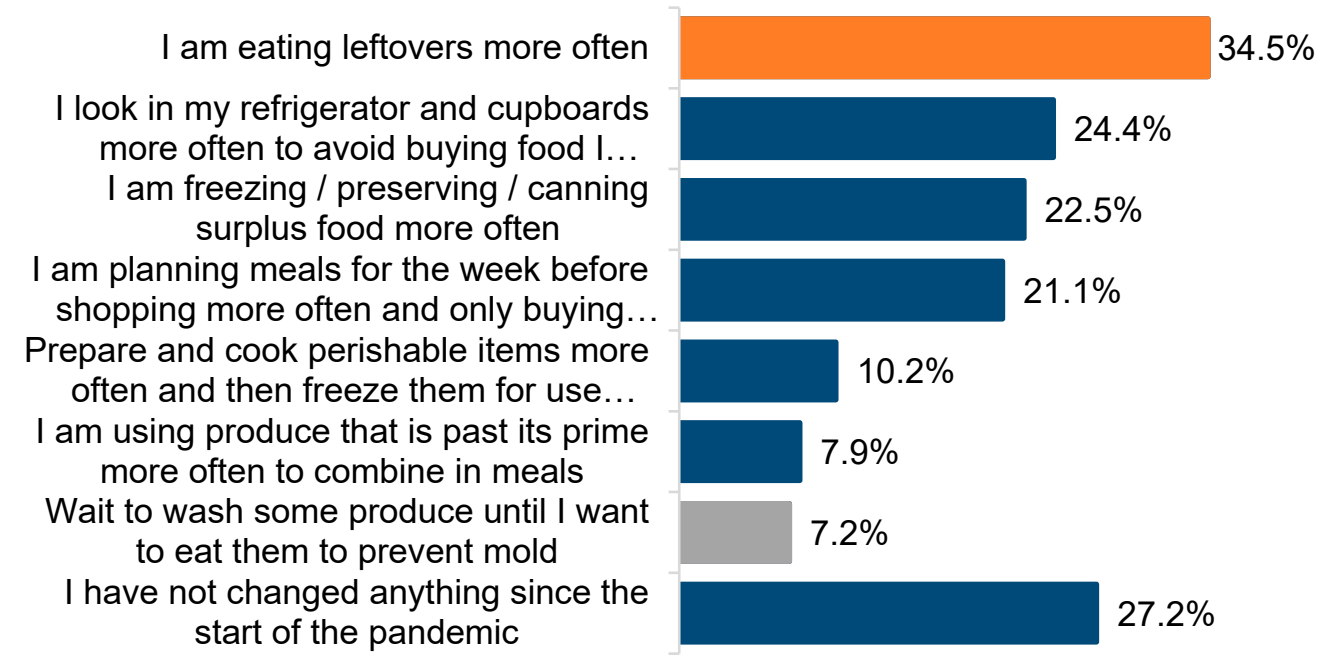

Figure 3. The self-reported results from a survey of Canadian residents on food waste and COVID-19. The responses indicate self-reported behaviour changes as a result of the pandemic.

\section{Discussion}

In the midst of the pandemic, there was a visible shock in consumer demand in Canada and other countries that resulted in panic buying and hoarding behaviours by consumers [28]. While panic buying and hoarding behaviours have reportedly ceased, the pandemic continues to have impacts on the daily lives of individuals, with rolling lockdowns still occurring in response to second and third waves. Social distancing measures remain in place, and many citizens continue to work from home across Canada. The restrictions in Canada and across the globe have changed since this survey was completed; further research should seek to replicate or complete a similar survey, as consumer behaviour may have changed since the time this survey was distributed (August 2020).

The results indicate that Canadians estimated that they were creating more food waste per household than before the onset of the pandemic; however, it is not clear whether there is a correlation to waste generation and the restrictions that have been implemented during the various stages of the pandemic. Lockdowns across the country have forced restaurants to severely restrict their food service capacity; at the same time [28], Canadians were forced to prepare more food at home, increasing household food waste [30]. To what extent that household food waste is offset by reduced commercial food waste is unknown. It could be that responsibility for food waste was transitioned from one food constituent to another. While this research found that self-reported food waste generated by Canadians at home has increased since the beginning of the pandemic, more research is needed to evaluate why this is the case. Future research could examine other key features of household behaviour prior to and after the pandemic, and the amount of time spent meal planning, cooking at home, and grocery shopping.

The main finding of this study, that household food waste has increased since before the pandemic, differs from research examining the impact of household food waste in other countries. Our results indicate that respondents estimated that their household generated slightly less food waste. Research conducted in Italy [12], Tunisia [55], Japan [15], and the United States [71] found that, during the early period of the pandemic, food waste decreased, while research in Serbia [39] and the UK [72] show, in some demographics, that food waste increased. There are several plausible explanations: food purchases were more commonly non-perishable products, consumers' risk aversion caused a greater amount of attention to be given to food consumption habits, such as purchasing more non-perishable products, and a general concern about the impact that the pandemic could potentially have 
on the waste management system. The underlying causes of the insignificant decrease in food waste in Canada are not yet understood, but these results indicated that many consumers discarded food because of poor planning behaviours. This is interesting, given the significant amount of time consumers were allotted by lockdowns and isolation public health measures. The impacts of child-rearing, work-life balance, stress, and apathy related to food planning are potential avenues for future research in examining the underlying causes of behaviour change, relating to the reported increase in food waste.

As this research has conflicting results in comparison to other research related to COVID-19 and food waste, future research should seek to examine the amount of household food waste in Canada through other research approaches, such as direct measurement of household food waste over time. Previous research has found that there is underreporting in self-assessment approaches to quantifying food waste $[73,74]$; for example, social desirability paired with limited memory capacity likely contributed to the accuracy of data that are self-reported by survey respondents [73]. In addition, the process involved in household food waste is spread over many days and occurs mostly unconsciously, which was found to lead to a generalized underestimation of individual contributions. Therefore, results of the present study should be interpreted with caution; the results indicate that there has been a notable change in the amount of food wasted in Canadian households, as a result of the COVID-19 pandemic. Future research should further examine this change and its potential to align with a shift to a more sustainable food system.

Future research should examine in more depth the behavioural changes that are associated with household food waste, in order to design effective strategies to reduce household food waste. Potential solutions related to consumer food waste and a sustainable food system include community supported agriculture, different strategies to incentivize switching to a more plant-based diet, and education on food waste minimization. These potential solutions should be explored further, as there is an urgent need to embrace the positive changes COVID-19 introduced at both individual and societal scales, such as the shift to community-supported agriculture.

\section{Conclusions}

The COVID-19 crisis has been framed by some as an opportunity to reflect on the transformation that is needed to develop a food system that regenerates and sustains the environment [43]. The destruction of habitats from industrialized livestock, the confinement of animals in small spaces, the narrowing of genetic diversity, and increased animal turnover increase the risk for zoonotic diseases [2]. The COVID-19 pandemic has created a new era during which the consequences for food systems are continuing to emerge, including the potential for a large-scale change within these systems [1]. It is crucial that responses to the pandemic shift from the traditional food chain practices mentioned, and involve developing creative solutions and sustainable food systems in order to be prepared for similar crises in the future. As the COVID-19 crisis continues to impact society on a global sale, the challenge will be to transform the reactions to the pandemic into new, foundational norms that prioritize reduction in food waste practices.

This study found that Canadian households have not significantly stopped wasting food since the beginning of the pandemic, according to self-reported results. Understanding food-waste behaviour changes is key to designing effective mitigation strategies to reduce household food waste, and to minimize the environmental consequences with which food waste is associated. The COVID-19 pandemic has brought weaknesses in the global food system to the forefront, and highlighted the urgent need to transform the current food system. Without drastic changes, similar crises will continue to unfold with unprecedented ramifications for global society.

Author Contributions: Conceptualization, S.C. and J.M.; methodology, S.C.; formal analysis, S.C. and J.M.; investigation, A.G. and S.F.; resources, J.M.; data curation, S.C.; writing-original draft preparation, A.G.; writing—review and editing, L.S., S.F. and J.M.; visualization, S.C.; supervision, 
J.M.; project administration, J.M.; funding acquisition, S.C. All authors have read and agreed to the published version of the manuscript.

Funding: This research was funded by Caddle, no grant number.

Institutional Review Board Statement: The study was conducted according to the guidelines of the Declaration of Helsinki, and approved by the Institutional Review Board (or Ethics Committee) of Dalhousie University on 15 July 2020 (protocol code \# 2020-5215).

Informed Consent Statement: Informed consent was obtained from all subjects involved in the study.

Data Availability Statement: Not available.

Conflicts of Interest: The authors declare no conflict of interest.

\section{References}

1. Galanakis, C.M. The Food Systems in the Era of the Coronavirus (COVID-19) Pandemic Crisis. Foods 2020, 9, 523. [CrossRef]

2. Giudice, F.; Caferra, R.; Morone, P. COVID-19, the Food System and the Circular Economy: Challenges and Opportunities. Sustainability 2020, 12, 7939. [CrossRef]

3. Helm, D. The Environmental Impacts of the Coronavirus. Environ. Resour. Econ. 2020, 76, 21-38. [CrossRef]

4. Van Damme, W.; Dahake, R.; Delamou, A.; Ingelbeen, B.; Wouters, E.; Vanham, G.; van de Pas, R.; Dossou, J.-P.; Ir, P.; Abimbola, S.; et al. The COVID-19 pandemic: Diverse contexts; different epidemics-How and why? BMJ Glob. Health 2020, 5, e003098. [CrossRef]

5. Kumar, A.; Gupta, P.K.; Srivastava, A. A review of modern technologies for tackling COVID-19 pandemic. Diabetes Metab. Syndr. Clin. Res. Rev. 2020, 14, 569-573. [CrossRef]

6. Pitlik, S.D. COVID-19 Compared to Other Pandemic Diseases. Rambam Maimonides Med. J. 2020, 11, e0027. [CrossRef] [PubMed]

7. Epifanio, M.S.; Andrei, F.; Mancini, G.; Agostini, F.; Piombo, M.A.; Spicuzza, V.; Riolo, M.; Lavanco, G.; Trombini, E.; La Grutta, S. The Impact of COVID-19 Pandemic and Lockdown Measures on Quality of Life among Italian General Population. J. Clin. Med. 2021, 10, 289. [CrossRef] [PubMed]

8. Biroli, P.; Bosworth, S.; Della Giusta, M.; Di Girolamo, A.; Jaworska, S.; Vollen, J. Family Life in Lockdown. Front. Psychol. 2021, 12, 687570. [CrossRef] [PubMed]

9. Zwanka, R.J.; Buff, C. COVID-19 Generation: A Conceptual Framework of the Consumer Behavioral Shifts to Be Caused by the COVID-19 Pandemic. J. Int. Consum. Mark. 2021, 33, 58-67. [CrossRef]

10. Mehta, S.; Saxena, T.; Purohit, N. The New Consumer Behaviour Paradigm amid COVID-19: Permanent or Transient? J. Health Manag. 2020, 22, 291-301. [CrossRef]

11. Howe, D.C.; Chauhan, R.S.; Soderberg, A.T.; Buckley, M.R. Paradigm shifts caused by the COVID-19 pandemic. Organ. Dyn. 2020, 100804. [CrossRef] [PubMed]

12. Pappalardo, G.; Cerroni, S.; Nayga, R.M.; Yang, W. Impact of Covid-19 on Household Food Waste: The Case of Italy. Front. Nutr 2020, 7, 291. [CrossRef] [PubMed]

13. Aldaco, R.; Hoehn, D.; Laso, J.; Margallo, M.; Ruiz-Salmón, J.; Cristobal, J.; Kahhat, R.; Villanueva-Rey, P.; Bala, A.; Batlle-Bayer, L.; et al. Food waste management during the COVID-19 outbreak: A holistic climate, economic and nutritional approach. Sci. Total Environ. 2020, 742, 140524. [CrossRef] [PubMed]

14. Schmitt, V.G.; Cequea, M.M.; Vásquez Neyra, J.M.; Ferasso, M. Consumption Behavior and Residential Food Waste during the COVID-19 Pandemic Outbreak in Brazil. Sustainability 2021, 13, 3702. [CrossRef]

15. Qian, K.; Javadi, F.; Hiramatsu, M. Influence of the COVID-19 Pandemic on Household Food Waste Behavior in Japan. Sustainability 2020, 12, 9942. [CrossRef]

16. Amicarelli, V.; Bux, C. Food waste in Italian households during the Covid-19 pandemic: A self-reporting approach. Food Secur. 2021, 13, 25-37. [CrossRef]

17. Principato, L.; Secondi, L.; Cicatiello, C.; Mattia, G. Caring more about food: The unexpected positive effect of the Covid-19 lockdown on household food management and waste. Socioecon. Plann. Sci. 2020, 100953. [CrossRef]

18. Bajželj, B.; Quested, T.E.; Röös, E.; Swannell, R.P.J. The role of reducing food waste for resilient food systems. Ecosyst. Serv. 2020, 45, 101140. [CrossRef]

19. Bellemare, M.F.; Cakir, M.; Peterson, H.H.; Novak, L.; Rudi, J. On the Measurement of Food Waste. Am. J. Agric. Econ. 2017, 99, 1148-1158. [CrossRef]

20. Jurgilevich, A.; Birge, T.; Kentala-Lehtonen, J.; Korhonen-Kurki, K.; Pietikäinen, J.; Saikku, L.; Schösler, H. Transition towards Circular Economy in the Food System. Sustainability 2016, 8, 69. [CrossRef]

21. Carroll, N.; Sadowski, A.; Laila, A.; Hruska, V.; Nixon, M.; Ma, D.W.L.; Haines, J.; on behalf of the Guelph Family Health Study. The Impact of COVID-19 on Health Behavior, Stress, Financial and Food Security among Middle to High Income Canadian Families with Young Children. Nutrients 2020, 12, 2352. [CrossRef]

22. Kabeer, N.; Razavi, S.; van der Meulen Rodgers, Y. Feminist Economic Perspectives on the COVID-19 Pandemic. Fem. Econ. 2021, 27, 1-29. [CrossRef] 
23. Yavorsky, J.E.; Qian, Y.; Sargent, A.C. The gendered pandemic: The implications of COVID-19 for work and family. Sociol. Compass 2021, 15, e12881. [CrossRef] [PubMed]

24. Belzunegui-Eraso, A.; Erro-Garcés, A. Teleworking in the Context of the Covid-19 Crisis. Sustainability 2020, 12, 3662. [CrossRef]

25. Riazi, N.A.; Wunderlich, K.; Gierc, M.; Brussoni, M.; Moore, S.A.; Tremblay, M.S.; Faulkner, G. “You Can't Go to the Park, You Can't Go Here, You Can't Go There": Exploring Parental Experiences of COVID-19 and Its Impact on Their Children's Movement Behaviours. Children 2021, 8, 219. [CrossRef] [PubMed]

26. Moore, S.A.; Faulkner, G.; Rhodes, R.E.; Brussoni, M.; Chulak-Bozzer, T.; Ferguson, L.J.; Mitra, R.; O’Reilly, N.; Spence, J.C.; Vanderloo, L.M.; et al. Impact of the COVID-19 virus outbreak on movement and play behaviours of Canadian children and youth: A national survey. Int. J. Behav. Nutr. Phys. Act. 2020, 17, 85. [CrossRef]

27. Qian, Y.; Fuller, S. COVID-19 and the Gender Employment Gap among Parents of Young Children. Can. Public Policy 2020, 46, S89-S101. [CrossRef]

28. Hobbs, J.E. Food supply chains during the COVID-19 pandemic. Can. J. Agric. Econ. Can. Agroecon. 2020, 68, 171-176. [CrossRef]

29. Cuschieri, S.; Grech, S. COVID-19: A one-way ticket to a global childhood obesity crisis? J. Diabetes Metab. Disord. 2020, 19, 2027-2030. [CrossRef]

30. Charlebois, S.; Music, J.; Faires, S. The Impact of COVID-19 on Canada's Food Literacy: Results of a Cross-National Survey. Int. J. Environ. Res. Public Health 2021, 18, 5485. [CrossRef]

31. Parfitt, J.; Barthel, M.; Macnaughton, S. Food waste within food supply chains: Quantification and potential for change to 2050 Philos. Trans. R. Soc. B Biol. Sci. 2010, 365, 3065-3081. [CrossRef]

32. Lebersorger, S.; Schneider, F. Food loss rates at the food retail, influencing factors and reasons as a basis for waste prevention measures. Waste Manag. 2014, 34, 1911-1919. [CrossRef]

33. Eriksson, M.; Spångberg, J. Carbon footprint and energy use of food waste management options for fresh fruit and vegetables from supermarkets. Waste Manag. 2017, 60, 786-799. [CrossRef]

34. Papargyropoulou, E.; Lozano, R.; Steinberger, J.K.; Wright, N.; bin Ujang, Z. The food waste hierarchy as a framework for the management of food surplus and food waste. J. Clean. Prod. 2014, 76, 106-115. [CrossRef]

35. Annosi, M.C.; Brunetta, F.; Bimbo, F.; Kostoula, M. Digitalization within food supply chains to prevent food waste. Drivers, barriers and collaboration practices. Ind. Mark. Manag. 2021, 93, 208-220. [CrossRef]

36. Roe, B.E.; Bender, K.; Qi, D. The Impact of COVID-19 on Consumer Food Waste. Appl. Econ. Perspect. Policy 2020, 43, 401-411. [CrossRef]

37. Wang, E.; An, N.; Gao, Z.; Kiprop, E.; Geng, X. Consumer food stockpiling behavior and willingness to pay for food reserves in COVID-19. Food Secur. 2020, 12, 1-9. [CrossRef] [PubMed]

38. Rodgers, R.F.; Lombardo, C.; Cerolini, S.; Franko, D.L.; Omori, M.; Linardon, J.; Guillaume, S.; Fischer, L.; Tyszkiewicz, M.F. "Waste not and stay at home" evidence of decreased food waste during the COVID-19 pandemic from the U.S. and Italy. Appetite 2021, 160, 105110. [CrossRef]

39. Berjan, S.; Vasko, Z.; Ben Hassen, T.; El Bilali, H.; Allahyari, M.S.; Tomić, V.; Radosavac, A. Assessment of household food waste management during the COVID-19 pandemic in Serbia: A cross-sectional online survey. Environ. Sci. Pollut. Res. 2021, 1-12. [CrossRef] [PubMed]

40. Richards, T.J.; Rickard, B. COVID-19 impact on fruit and vegetable markets. Can. J. Agric. Econ. Can. Agroecon. 2020, 68, 189-194. [CrossRef]

41. Bender, K.E.; Badiger, A.; Roe, B.E.; Shu, Y.; Qi, D. Consumer behavior during the COVID-19 pandemic: An analysis of food purchasing and management behaviors in U.S. households through the lens of food system resilience. Socioecon. Plan. Sci. 2021, 101107. [CrossRef]

42. Amato, M.; Verneau, F.; Coppola, A.; La Barbera, F. Domestic Food Waste and Covid-19 Concern: An Application of the Theory of Planned Behaviour. Sustainability 2021, 13, 8366. [CrossRef]

43. Ghinoi, S.; Silvestri, F.; Steiner, B. Toward the creation of novel food waste management systems: A network approach. J. Clean. Prod. 2020, 246, 118987. [CrossRef]

44. Sharma, R.; Dhir, A.; Talwar, S.; Kaur, P. Over-ordering and food waste: The use of food delivery apps during a pandemic. Int. J. Hosp. Manag. 2021, 96, 102977. [CrossRef]

45. Zhao, Y.; Bacao, F. What factors determining customer continuingly using food delivery apps during 2019 novel coronavirus pandemic period? Int. J. Hosp. Manag. 2020, 91, 102683. [CrossRef]

46. Muangmee, C.; Kot, S.; Meekaewkunchorn, N.; Kassakorn, N.; Khalid, B. Factors Determining the Behavioral Intention of Using Food Delivery Apps during COVID-19 Pandemics. J. Theor. Appl. Electron. Commer. Res. 2021, 16, 1297-1310. [CrossRef]

47. Mehrolia, S.; Alagarsamy, S.; Solaikutty, V.M. Customers response to online food delivery services during COVID-19 outbreak using binary logistic regression. Int. J. Consum. Stud. 2021, 45, 396-408. [CrossRef]

48. Mullins, L.; Charlebois, S.; Finch, E.; Music, J. Home Food Gardening in Canada in Response to the COVID-19 Pandemic. Sustainability 2021, 13, 3056. [CrossRef]

49. Music, J.; Finch, E.; Gone, P.; Toze, S.; Charlebois, S.; Mullins, L. Pandemic Victory Gardens: Potential for local land use policies. Land Use Policy 2021, 109, 105600. [CrossRef]

50. Thilmany, D.; Canales, E.; Low, S.A.; Boys, K. Local Food Supply Chain Dynamics and Resilience during COVID-19. Appl. Econ. Perspect. Policy 2021, 43, 86-104. [CrossRef] 
51. Chiffoleau, Y.; Dourian, T. Sustainable Food Supply Chains: Is Shortening the Answer? A Literature Review for a Research and Innovation Agenda. Sustainability 2020, 12, 9831. [CrossRef]

52. Kumari, A.; Ranjan, P.; Vikram, N.K.; Kaur, D.; Sahu, A.; Dwivedi, S.N.; Baitha, U.; Goel, A. A short questionnaire to assess changes in lifestyle-related behaviour during COVID 19 pandemic. Diabetes Metab. Syndr. 2020, 14, 1697-1701. [CrossRef] [PubMed]

53. Kitz, R.; Walker, T.; Charlebois, S.; Music, J. Food packaging during the COVID-19 pandemic: Consumer perceptions. Int. J. Consum. Stud. 2021, 45, 10. [CrossRef] [PubMed]

54. Scacchi, A.; Catozzi, D.; Boietti, E.; Bert, F.; Siliquini, R. COVID-19 Lockdown and Self-Perceived Changes of Food Choice, Waste, Impulse Buying and Their Determinants in Italy: QuarantEat, a Cross-Sectional Study. Foods 2021, 10, 306. [CrossRef]

55. Jribi, S.; Ben Ismail, H.; Doggui, D.; Debbabi, H. COVID-19 virus outbreak lockdown: What impacts on household food wastage? Environ. Dev. Sustain. 2020, 22, 3939-3955. [CrossRef]

56. Sadhukhan, J.; Dugmore, T.I.J.; Matharu, A.; Martinez-Hernandez, E.; Aburto, J.; Rahman, P.K.S.M.; Lynch, J. Perspectives on "Game Changer" Global Challenges for Sustainable 21st Century: Plant-Based Diet, Unavoidable Food Waste Biorefining, and Circular Economy. Sustainability 2020, 12, 1976. [CrossRef]

57. Chai, B.C.; van der Voort, J.R.; Grofelnik, K.; Eliasdottir, H.G.; Klöss, I.; Perez-Cueto, F.J.A. Which Diet Has the Least Environmental Impact on Our Planet? A Systematic Review of Vegan, Vegetarian and Omnivorous Diets. Sustainability 2019, 11, 4110. [CrossRef]

58. Charlebois, S.; Somogyi, S.; Music, J.; Caron, I. Planet, Ethics, Health and the New World Order in Proteins. J. Agric. Stud. 2020, 8, 171. [CrossRef]

59. Maragoni-Santos, C.; Serrano Pinheiro de Souza, T.; Matheus, J.R.V.; de Brito Nogueira, T.B.; Xavier-Santos, D.; Miyahira, R.F.; Costa Antunes, A.E.; Fai, A.E.C. COVID-19 pandemic sheds light on the importance of food safety practices: Risks, global recommendations, and perspectives. Crit. Rev. Food Sci. Nutr. 2021, 1-13. [CrossRef]

60. Men, F.; Tarasuk, V. Food Insecurity amid the COVID-19 Pandemic: Food Charity, Government Assistance, and Employment. Can. Public Policy 2021, 47, 202-230. [CrossRef]

61. Scherhaufer, S.; Moates, G.; Hartikainen, H.; Waldron, K.; Obersteiner, G. Environmental impacts of food waste in Europe. Waste Manag. 2018, 77, 98-113. [CrossRef] [PubMed]

62. Johnson, J.M.-F.; Franzluebbers, A.J.; Weyers, S.L.; Reicosky, D.C. Agricultural opportunities to mitigate greenhouse gas emissions. Environ. Pollut. 2007, 150, 107-124. [CrossRef]

63. Yue, Q.; Xu, X.; Hillier, J.; Cheng, K.; Pan, G. Mitigating greenhouse gas emissions in agriculture: From farm production to food consumption. J. Clean. Prod. 2017, 149, 1011-1019. [CrossRef]

64. Ertan, D.; Yavuz, C.M.; Kagan, T. Landfill Settlement with Decomposition and Gas Generation. J. Environ. Eng. 2005, 131, 1311-1321. [CrossRef]

65. Wang, Y.-S.; Odle, W.S., III; Eleazer, W.E.; Barlaz, M.A. Methane potential of food waste and anaerobic toxicity of leachate produced during food waste decomposition. Waste Manag. Res. 1997, 15, 149-167. [CrossRef]

66. Behera, S.K.; Park, J.M.; Kim, K.H.; Park, H.-S. Methane production from food waste leachate in laboratory-scale simulated landfill. Waste Manag. 2010, 30, 1502-1508. [CrossRef] [PubMed]

67. Laurance, W.F.; Sayer, J.; Cassman, K.G. Agricultural expansion and its impacts on tropical nature. Trends Ecol. Evol. 2014, 29, 107-116. [CrossRef]

68. Davis, M.; Ahiduzzaman, M.; Kumar, A. How will Canada's greenhouse gas emissions change by 2050? A disaggregated analysis of past and future greenhouse gas emissions using bottom-up energy modelling and Sankey diagrams. Appl. Energy 2018, 220, 754-786. [CrossRef]

69. Patrício Silva, A.L.; Prata, J.C.; Walker, T.R.; Campos, D.; Duarte, A.C.; Soares, A.M.V.M.; Barcelò, D.; Rocha-Santos, T. Rethinking and optimising plastic waste management under COVID-19 pandemic: Policy solutions based on redesign and reduction of single-use plastics and personal protective equipment. Sci. Total Environ. 2020, 742, 140565. [CrossRef]

70. Best, L.A.; Law, M.A.; Roach, S.; Wilbiks, J.M.P. The psychological impact of COVID-19 in Canada: Effects of social isolation during the initial response. Can. Psychol. Can. 2021, 62, 143-154. [CrossRef]

71. Cosgrove, K.; Vizcaino, M.; Wharton, C. COVID-19-Related Changes in Perceived Household Food Waste in the United States: A Cross-Sectional Descriptive Study. Int. J. Environ. Res. Public Health 2021, 18, 1104. [CrossRef]

72. Armstrong, B.; Reynolds, C.; Martins, C.A.; Frankowska, A.; Levy, R.B.; Rauber, F.; Osei-Kwasi, H.A.; Vega, M.; Cediel, G.; Schmidt, X.; et al. Food insecurity, food waste, food behaviours and cooking confidence of UK citizens at the start of the COVID-19 lockdown. Br. Food J. 2021, 123, 2959-2978. [CrossRef]

73. Delley, M.; Brunner, T.A. Household food waste quantification: Comparison of two methods. Br. Food J. 2018, 120, 1504-1515. [CrossRef]

74. Ellison, B.; Lusk, J.L. Examining Household Food Waste Decisions: A Vignette Approach. Appl. Econ. Perspect. Policy 2018, 40, 613-631. [CrossRef] 